\title{
The Pope's Universities: Sources and Research Perspectives on Finances and Funding in the Early Modern Period in Bologna
}

\author{
Las universidades papales: fuentes y perspectivas de \\ investigación sobre finanzas y financiación en Bolonia \\ en la temprana Edad Moderna
}

\author{
Maria Teresa Guerrini* \\ University of Bologna - Alma Mater Studiorum
}

Recibido: $\quad 03 / 03 / 2021$

Aceptado: $\quad$ 23/04/2021

DOI: https://doi.org/10.20318/cian.2021.6158

\begin{abstract}
The contribution aims to propose a first overview on the founding universities subject in the Papal State during the $16^{\text {th }}-18^{\text {th }}$ centuries. Although there were nine universities in the Church State in this period, the research is going to focus on the most relevant and ancient of them: Bologna, Perugia and Rome. The history of these three Studia is well known, but the specific topic concerning finances and founding has not been broadly analysed. In particular, regarding this topic, the focus will be on the feature that distinguish the situation in the University of Bologna, during the early modern period, when the tradition of political autonomy of the town
\end{abstract}

Resumen: El presente artículo tiene como objetivo proponer una primera panorámica sobre el tema de la financiación de las Universidades en el Estado Pontificio durante los siglos XVI-XVIII. Aunque hubo nueve universidades en el Estado de la Iglesia en este período, la investigación se centrará en las más relevantes y antiguas: Bolonia, Perugia y Roma. La historia de estos tres Studia es bien conocida, pero el tema específico de las finanzas no ha sido ampliamente analizado. En particular, en relación con esta cuestión, se analizará la situación en la Universidad de Bolonia, durante el período moderno, donde la tradición política autonómica de la ciudad condicionó en

\footnotetext{
"mariateresa.guerrini@unibo.it
} 
conditioned the development of the University. The condition of the sources will be a focal point in the essay. These three cases could therefore offer the opportunity to compare different situations and to verify the action of the State towards an increasing uniformity. Keywords: Bologna; Rome; Perugia; management; funding. gran medida el desarrollo de la Universidad. En particular, se prestarà especial atención al estado de las fuentes. Por tanto, estos tres casos podrían ofrecer la oportunidad de comparar diferentes situaciones y verificar la acción del Estado hacia una uniformidad cada vez mayor. Palabras clave: Bolonia; Roma; Perugia; gestión; financiación.

\section{The financial situation of the three main Universities in the Papal State}

Since the Middle Ages University corporations had their own budget. Generally, University funding came from both internal and external sources: internal sources were matriculation and graduation fees, graces, dispensations, collectae. External sources were ecclesiastical benefices. Salaries, gifts, legacies, grants and endowments were often paid by political authorities (kings, dukes or towns) for the permanent support of the University ${ }^{1}$. So different universities had varied experiences in relation to the geo-political context ${ }^{2}$.

As regards the Bologna situation, during the early modern age, this town was direct conducted under the political Pontifical control since 1506, but many privileges were recognized by popes to the Senate (composed by aristocratic people), to guarantee a local ally ${ }^{3}$. We are therefore in the presence of a particular political situation that also had significant consequences on the University administration and finances until the French revolution. One of these new privileges assigned by popes to the Senate, at the beginning of the $16^{\text {th }}$ century, was in fact the right to appoint University professors

\footnotetext{
${ }^{1}$ An overview of the situation in the Middle Ages is in Aleksander Gierysztor, "Management and resources", A history of the University in Europe. Volume I. Universities in the Middle Ages, ed. Hilde de Ridder-Symoens (Cambridge: Cambridge University Press, 1992), 108-143 and for the Early Modern Europe see Hilde de Ridder-Symoens, "Management and resources", A history of the University in Europe. Volume II. Universities in Early Modern Europe, ed. Hilde de Ridder-Symoens (Cambridge: Cambridge University Press, 1996), 155-209.

${ }^{2}$ For the Italian universities situation see Andrea Romano, “Dall'Università degli Studenti all'Università degli Studi. Modelli di finanziamento delle Università italiane fra medioevo ed età moderna", Finanzierung von Universität und Wissenschaft in Vergangenheit und Gegenwart, ed. Rainer Christoph Schwinges (Basel : Schwabe Verlag, 2005), 33-56.

${ }^{3}$ Andrea Gardi, "Lineamenti della storia politica di Bologna: da Giulio II a Innocenzo X", Storia di Bologna. Bologna nell'età moderna. I. Istituzioni, forme del potere, economia e società, ed. Adriano Prosperi (Bologna : Bononia University Press, 2008), 3-59. On this topic see also Id., Lo Stato in provincia. L'amministrazione della Legazione di Bologna durante il regno di Sisto $V$ (1585-1590) (Bologna : Istituto per la storia di Bologna, 1994); Angela De Benedictis, Repubblica per contratto, Bologna: una città europea nello Stato della Chiesa (Bologna : il Mulino, 1995).
} 
(privilege previously recognized to the Riformatori dello Studio, a municipal institution $)^{4}$ : a local political authority was invested of a cultural power.

Alfeo Giacomelli started studying the unique characteristics of the political situation in the early modern period in the University of Bologna since 1432, when Eugenio IV stated that the salaries of the professors should be paid with the incomes of the Gabella Grossa (a tax on goods entering in Bologna $)^{5}$. This happened in the other main Pope's Universities, at the beginning of the $15^{\text {th }}$ century (like Rome and Perugia) ${ }^{6}$, when the popes wanted to regularize the chaotic financial situations. First, in Perugia Martino $\mathrm{V}$ centralized all the finances, previously managed by the local Conservatori della moneta, on behalf of the Reverenda Camera Apostolica in Rome ${ }^{7}$. Second, Bologna and Rome followed closely, with the Eugenio IV decisions that rationalized the organization of these two universities: the Alma Mater Studiorum was financed with the Gabella Grossa incomes, in parallel the Sapienza of Rome was held with the new Gabella dello Studio founded on taxes on foreign wines ${ }^{8}$.

The three Pope's universities had different characteristics: in both Perugia and Rome, during the early modern period, the Camera Urbis (based in the Roman Curia) managed the incomes for the direction of the two Studia. In Bologna, however, there was grater autonomy and the administration of the local University was free from any Pontifical interference.

${ }^{4}$ About the Riformatori dello Studio see L'archivio dei Riformatori dello Studio. Inventario, ed. Claudia Salterini (Bologna : Istituto per la storia dell'Università, 1997).

${ }^{5}$ Alfeo Giacomelli, "L'età moderna (dal XVI al XVIII secolo)", L'Università a Bologna. Maestri, studenti e luoghi dal XVI al XX secolo (Bologna : Cassa di Risparmio, 1988), 13. In case that the amount of money was insufficient, the expenses for the Studio were paid with the Dazio del Sale and, as a last resort, with all the duties of the city.

${ }^{6}$ See the papers analysed in the $8^{\text {th }}$ Heloise Atelier, Universities funding and management (Lisbon, 22-24 October 2018) by Carla Frova (The financing of the University of Rome, 14th15th Centuries), by Stefania Zucchini (The financing of the University of Perugia, 14th-15th Centuries) and by Regina Lupi (Funding and financing the University of Perugia in the early modern age). About the early modern period see also Regina Lupi, Gli studia del papa. Nuova cultura e tentativi di riforma tra Sei e Settecento (Firenze : Centro Editoriale Toscano, 2005).

${ }^{7}$ Stefania Zucchini, Università e dottori nell'economia del comune di Perugia (Perugia : Deputazione di storia patria per l'Umbria, 2008), 39-53 and more in general in chapter 2. About this topic see also Giuseppe Ermini, Storia dell'Università di Perugia, t. 1 (Bologna : Zanichelli, 1947), 262, 269-272.

${ }^{8}$ Regarding the situation in Rome see Filippo Maria Renazzi, Storia dell'Università degli studi di Roma. Detta comunemente la Sapienza che contiene anche un saggio storico della letteratura romana, dal principio del secolo XIII sino al declinare del secolo XVIII (Roma : stamperia Pagliarini, 1806) and Maria Rosa Di Simone, La Sapienza romana nel Settecento. Organizzazione, università e insegnamento del diritto (Roma : Edizioni dell'Ateneo, 1980), 43-44. 
The situation at the University of Bologna

Coming back to the Bologna situation, the next pope, Niccolò V, in 1450-51 set the number of teachings ( 46 reserved to local professors and 4 booked for foreigners) and also fixed the maximum salary for any professor (400/500 lire di bolognini per year) ${ }^{9}$.

Until the beginning of the $16^{\text {th }}$ century the administration of the Gabella in Bologna was under the control of a local Treasurer. With Giulio II, in 1509 , this control passed under a close commission composed by six doctors (two for any doctoral College) ${ }^{10}$ : in this way the University economic power switched to the doctoral class. Clemente VII, in 1523, finally fixed the salaries at 26.000 lire di bolognini and increased the Gabella's duties by 8.000 lire di bolognini ${ }^{11}$.

For the whole early modern period the professor salaries in Bologna was therefore paid with the Gabella Grossa incomes and the members of doctoral Colleges deprived the ancient institution of the Riformatori dello Studio of their economic power ${ }^{12}$. Several local professors were paid with the incomes from the Gabella Grossa, while the few foreign teachers (doctores forenses eminentis scientiae) were paid by the Depositeria, a local political office. The eminenti were professors who had a great reputation and an incredible knowledge. Since the Middle Ages in Bologna there were four chairs for eminenti professors: Civil and Canon Law lectures were scheduled in the afternoon and two other eminenti professors gave Medicine, Philosophy and Humanities lectures ${ }^{13}$. Mariano Sozzini, the Younger, was in Bologna

\footnotetext{
${ }^{9}$ Giacomelli, L'età moderna, 14.

${ }^{10}$ In the Bologna Studium there were three doctoral Colleges: the College of Canon Law, the College of Civil Law and a College of Medicine and Philosophy. See Gian Paolo Brizzi, "Lo Studio di Bologna fra orbis academicus e mondo cittadino", Storia di Bologna. Bologna nell'età moderna. II. Cultura, istituzioni culturali, Chiesa e vita religiosa, ed. Adriano Prosperi (Bologna: Bononia University Press, 2008) 5-113, in particular 40-42.

${ }^{11}$ Anton Felice Marsili, Memorie per riparare i pregiudizi dell'Università dello Studio di Bologna, e ridurlo ad una facile e perfetta riforma (Bologna : s.l., 1689) in Ettore Bortolotti, "La fondazione dell'Istituto e la Riforma dello Studio di Bologna", Memorie intorno a Luigi Ferdinando Marsili pubblicate nel secondo centenario della morte per cura del Comitato Marsiliano (Bologna : Zanichelli, 1930) 3.

${ }^{12}$ See note 4.

${ }^{13}$ Anuschka De Coster, "Foreign and Citizen Teachers at Bologna University in the $15^{\text {th }}$ and $16^{\text {th }}$ Centuries: Statutes, Statistics and Student Teachers", Annali di Storia delle Università italiane 12 (2008): 329-356; Ead., "L'immagine dei docenti forestieri negli statuti universitari e cittadini di Bologna e Padova (secoli XV-XVI)", Gli Statuti universitari. Tradizione dei testi e valenze politiche, Atti del Convegno internazionale di studi, Messina-Milazzo, 13-18 aprile 2004,
} 
the main eminente lecturer but Carlo Ruini, Andrea Alciato and Angelo Spanocchi were appointed foreign lecturers too. Among others, Romolo Amaseo and Carlo Sigonio gave humanities teachings. Usually in Bologna citizen lecturers were appointed the professorship and four chairs were assigned to non-resident, to build a reputation of the Studium. The same thing didn't happen in Perugia where all the teachers were local. In Dallari's list of professors in Bologna, in early modern period, foreign professors were about $40 \%$ of the teachers ${ }^{14}$. The number of foreign professors increased because of the high number of lecturae universitatis assigned to young foreign students to help them with graduation expenses (the salary for these lectures was 100 lire). At the beginning of the $17^{\text {th }}$ century there were about 90 active teachers at the University of Bologna: about 40 chairs were appointed to citizens and the rest were appointed to foreigners (a smaller number of chairs for eminenti and many lecturae universitatis for students) ${ }^{15}$.

In Bologna there was a salary hierarchy, which is confirmed by the lecturae universitatis. In the first half of the $16^{\text {th }}$ century, the salary of a young teacher generally was 200 lire of bolognini and the salary of an ordinary professor could reach 2.000 lire of bolognini. The four doctores forenses eminentis scientiae were well paid: in 1530 Carlo Ruini received 4.330 lire for Civil Law lecture; Giovanni Angelo Papio, in 1581 received a salary of 4.250 lire $^{16}$. The characteristic of the salary at the University of Bologna was that Bolognese lecturers earned a modest income, while the four eminenti had a wellpaid salary. The limited number of eminenti allowed the University to save money, which they used to increase the number of local professors.

The situation described for Bologna changed significantly at the beginning of the $17^{\text {th }}$ century when Clemente VIII introduced into the Congregazione della Gabella Grossa seven senators, connected to the Assunti di Stu-

ed. Andrea Romano (Bologna : CLUEB, 2007), 813-824; Ead. "La mobilità dei docenti: Comune e Collegi dottorali di fronte al problema dei lettori non cittadini nello Studio bolognese", Studenti e dottori nelle università italiane (origini-XX secolo), ed. Gian Paolo Brizzi - Andrea Romano (Bologna : CLUEB, 2000) 227-241.

${ }^{14}$ Umberto Dallari, I Rotuli dei lettori, legisti e artisti dello Studio bolognese (Bologna : F.lli Merlani, 1888-1924).

${ }^{15}$ See my paper for the $10^{\text {th }}$ Atelier Heloise, held on 29-30 March 2021 for a detailed description of foreign teachers in Bologna: Professors in motion. The mobility of Bolognese teachers in early modern period (in print).

${ }^{16}$ Andrea Zannini, "I Maestri: carriere, metodi didattici, posizione sociale, rapporti con le professioni", Storia delle Università in Italia, t. II, eds. Gian Paolo Brizzi, Piero Del Negro, Andrea Romano (Messina : Sicania, 2007), 37-63. 
dio, to balance the doctoral power: this decision caused a lot of problems ${ }^{17}$. The Assunteria di Studio was founded at the beginning of the $16^{\text {th }}$ century to examine special issues ${ }^{18}$. It was an extraordinary commission, composed by three senators, that became ordinary and permanent a few years later ${ }^{19}$. The Assunti di Studio examined, on behalf of the Senate, the procedures related to teaching and the contents of the lessons. Every deal they have dealt with is also represented in the documentation of the Senate. As time passed the Assunti gained more autonomous to the point that the Bolognese ambassador in Rome wrote directly to them and received a reply from them.

The structural economic crisis during this century also exasperated the conflicts between doctors and senators (also through the Assunti di Studio); between the doctoral Colleges; between the archdeacon (in Bologna chancellor of the University instead of the bishop) ${ }^{20}$ and the doctoral Colleges $^{21}$. The archdeacon Anton Felice Marsili was the center of these conflicts. He was the brother of the well-known general Luigi Ferdinando, who contributed to the funding of the Istituto delle Scienze in Bologna ${ }^{22}$. The archdeacon Marsili held the doctors of the Colleges accountable for the decline

${ }^{17}$ Giacomelli, L'età moderna, 14.

${ }^{18}$ In order to be able to meticulously control all areas of public life in Bologna, from the first half of the $16^{\text {th }}$ century the Senate decided to found different commissions, and each of them was designated for a specific subject. The Assunti were selected by drawing lot among the senators and elected by the Senate. Their term of office was one year. There were permanent commissions too. Among those the commission of Magistrates represented the most important, as it had the task of ensuring that the activity of the legates did not affect the rights granted to the city; other assunterie were extraordinary, ad hoc commissions, that were established at the time when a specific need arose. About this topic see Angela De Benedictis, Patrizi e comunità. Il governo del contado bolognese nel Settecento (Bologna : il Mulino, 1984).

${ }^{19}$ Giorgio Cencetti, Lo Studio di Bologna. Aspetti momenti e problemi (1935-1970), eds. Roberto Ferrara, Gianfranco Orlandelli, Augusto Vasina (Bologna : CLUEB, 1989), 336-339.

${ }^{20}$ Riccardo Parmeggiani, "Larcidiacono bolognese tra Chiesa, città e Studium", L'Università in tempo di crisi. Revisioni e novità dei saperi e delle istituzioni nel Trecento, da Bologna all'Europa, eds. Berardo Pio - Riccardo Parmeggiani (Bologna : CLUEB, 2016), 95-111.

${ }^{21}$ An analysis in Maria Teresa Guerrini, Collegi dottorali in conflitto. I togati bolognesi e la Costituzione di Benedetto XIV (1744) (Bologna : CLUEB, 2012); Ead., "Conflitti corporativi fra dottori bolognesi, ferraresi e romani intorno a titoli accademici e professioni (1626-1795)", Un monopolio imperfetto. Titoli di studio, professioni, università (secc. XIV-XXI), eds. Maria Teresa Guerrini, Regina Lupi, Maria Malatesta (Bologna : il Mulino, 2016), 59-80.

${ }^{22}$ Marta Cavazza, "Riforma dell'Università e nuove accademie nella politica culturale dell'Arcidiacono Marsili", Università, Accademie e Società scientifiche in Italia e in Germania dal Cinquecento al Settecento, eds. Laetitia Boehm and Ezio Raimondi (Bologna : il Mulino, 1981) 245-282; Ead., Settecento inquieto. Alle origini dell'Istituto delle Scienze di Bologna (Bologna : il Mulino, 1990). 
of the studies in Bologna ${ }^{23}$ and for the decline of the responsibilities of the Chancellor of the Studium ${ }^{24}$.

At the end of the $17^{\text {th }}$ century, when the archdeacon Marsili directed his invective at the Colleges of doctors, the economic crisis hit Bologna and also the Gabella incomes fell (from 65.000 lire di bolognini to 53.000) and the outputs grew as a result of a thoughtless progressive increase of the number of professors (according to wrong equivalence: many professors = grater fame $)^{25}$. In 1677 there were 122 teachers registered in the Rotuli, although they had been set at $46^{26}$. The solutions adopted was a snap block of teachings (that passed to 70) and a reform of lectures in 1713 that rationalized the whole system ${ }^{27}$. But benefits didn't last over time: from the annual restored amount of 28.000 lire di bolognini the expenses for salaries quickly grew up over 44.000 lire di bolognini ${ }^{28}$.

This critical financial situation was destined to stay until the French revolution when the University of Bologna passed completely under the control of the State and here we are a synthetic overview on the main documents, kept in Bologna archives, about this subject.

\section{The financial sources}

Many magistrates were mobilized to support the complex organization of the University in Bologna ${ }^{29}$. Each of the offices had its own archive, and today all their documents are mainly kept at the local State Archive. We can find documents from the doctoral Colleges (civil and canon law, medicine and philosophy) and from the Universities of students (universitates scholarium)

\footnotetext{
${ }^{23}$ Anton Felice Marsili, Memorie per riparare i pregiudizi dell'Università dello Studio di Bologna, e ridurlo ad una facile e perfetta riforma.

${ }^{24}$ Anton Felice Marsili, Delle prerogative del Cancellierato Maggiore dello Studio generale di Bologna carico depositato nell'Arcidiacono della Metropolitana di essa Città raccolte da monsignore Antonio Felice Marsili moderno Arcidiacono, e Maggior Cancelliere (Bologna : s.l., 1692). See Lupi, Gli studia del papa, 62-66.

${ }^{25}$ Giacomelli, L'età moderna, 20.

${ }^{26}$ Ibidem.

${ }^{27}$ Franca Baldelli, "Tentativi di regolamentazione e riforme dello Studio bolognese nel Settecento", Il Carrobbio 10 (1984): 10-26.

${ }^{28}$ Bologna, Archivio di Stato, Assunteria di Studio, Diversorum, b. 93: the exact annual amount was 44060.14.11 (in a local monetary system based on lire bolognine, soldi, denari).

${ }^{29}$ A detailed description of the magistrates involved in the local Studium can be found in Cencetti, Lo Studio di Bologna. Aspetti momenti e problemi (1935-1970), 313-344.
} 
that are kept in the Studio collection. Other documents are stored in the collections of the Riformatori dello Studio, Congregazione di Gabella Grossa and Assunteria di Studio. Finally there are numerous documentary traces in the archives of the Comune, in particular in the archive that belonged to the Senate. In order to study finances of the University it is necessary to make cross references between all these documents.

In the late medieval period the office of the Riformatori dello Studio had a great authority managing the University. In the middle of the $14^{\text {th }}$ century students started having less autonomy after the Comune (the Municipality) had gained more responsibilities in Studio. A sign of this change came with the creation of the judiciary of the Riformatori dello Studio, which originate from the municipal office of the Elders (the Anziani) ${ }^{30}$. From then on, the students could not choose professors. They were elected by the Reformes who were responsible for drawing up the Rotuli (the annual lists of teachers with the timetable of courses, one for lawyers and another for artists) that were published and hung in various places in town. This judiciary also had the task of monitoring the work of professors, penalizing those who were frequently absent and those who did not have enough students. The report, called punctatio, established a fine that was the exact amount of a day's salary imposed by the punctator. This collection of documents is therefore important because they provide information with a focus on the teaching activities in the University, the lists of professors, the penalties imposed on them that had repercussions on their wages, which were paid every three months, four time a year, and for this reason were called quartironi. These documents stated, next to the name of each professor, their annual salary and the total amount of the punctationes. The authorization to the depositary of the Gabella Grossa to issue the payment is in a footnote at the bottom of the document. This collection is very important for the studies on the University of Bologna because we can compare wages, read the complete list of professors and understanding the changes that occurred throughout a year for each course (fines, reserved seats, a record of retired and deceased professors). For this reason we often find inconsistencies between the Rotuli and the Quartironi: it would be useful to cross reference between these two series of documents, that are kept in the Riformatori dello Studio collection ${ }^{31}$, in order to have a better understanding of reality.

\footnotetext{
${ }^{30}$ L'Archivio dei Riformatori dello Studio. Inventario.

${ }^{31}$ Bologna, Archivio di Stato, Riformatori dello Studio, Rotuli dei lettori (1438-1800), b. 2-13; Quartironi degli stipendi (1461-1796), b. 38-55; Puntationi dei lettori (1465-1513, 1702-1795), b. 15-22.
} 
Many other sources, about the economic life of Bologna University, are kept in these three documentary collections: Congregazione di Gabella Grossa, Studio and Assunteria di Studio.

The State Archive of Bologna keeps the documents about the expenses of the Studio that consists in the statements of incomes and expenses for the period 1600-1797 (Libri giornale and Libri mastri with the detail of each item held in the Fondo of the Congregazione di Gabella Grossa) ${ }^{32}$, the lists of rates (Tariffari kept in the Fondo Studio), the lists of paid persons (Salariati conserved in the Fondo Assunteria di Studio that show how many University people were paid with the money taken from the Gabella: the teachers but also the writer and the printer of the Rotuli, the writer of calendars, the writer of the quartironi, the anatomist and the anatomy ceremony, the lecture universitatis held by good students, the guardian of the Schools, the guardian of the Botanic Garden - il Giardino de' Semplici) ${ }^{33}$.

In particular a group of sheets could be interesting because they speak about the Archiginnasio building costs. Before the middle of the $16^{\text {th }}$ century the Congregazione di Gabella Grossa paid the rent of houses destined to host the University lessons. In 1561 the vicelegato Pier Donato $\mathrm{Cesi}^{34}$ decided to build a new seat for Schools near the church of San Petronio, to better control the students. The Pope didn't pay anything for this project. The whole costs in fact were leaning against the Gabella Grossa. The Archiginnasio was opened in 1563 and the Gabella spent 63.502 lire di bolognini (corresponding to approximately 14.000 Roman scudi) on the building process ${ }^{35}$. In addition, each month the Gabella sindaci should pay 146 lire di bolognini to the San Petronio church for the rent of the domain and for the Archiginnasio facilities maintenance and 10 lire di bolognini to the bidello (beadle) of the Schools ${ }^{36}$. The building continued to be property of Gabella Grossa who forbade the Senate to place an epigraph in the memory of the founding.

${ }^{32}$ Bologna, Archivio di Stato, Congregazione di Gabella Grossa, Spese di Studio, b. 55.

${ }^{33}$ Ivi, Studio, b. 204, 231, 231bis, Tariffe, statuti e capitoli di Gabella (1580-1678) and Assunteria di Studio, Salariati, b. 5, 7, 92 (1400-1748, 1790-1797).

${ }^{34}$ Cesi was the bishop of Narni and in Bologna he replaced the legato Carlo Borromeo involved in ecclesiastical affairs, on behalf of the Pope, in both Milan and Rome.

${ }^{35}$ Bologna, Archivio di Stato, Congregazione di Gabella Grossa, Diversorum, b. 96. The first beadle was Gherardo da Panico (on the bidello rule see Antonio Ivan Pini, "Per una storia sociale dell'Università: i bidelli bolognesi nel XIII secolo", Studio, università e città nel medioevo bolognese (Bologna : CLUEB, 2005), 288-323.

${ }^{36}$ Ivi, Assunteria di Studio, Diversorum, b. 96, 5. 
The expenses for wall decorations, with students' coat of arms, instead were paid with the Collecta Nivis (a tax paid by the city authorities to student representatives specifically for the first winter snowfall) ${ }^{37}$.

Another chapter in this overview on the economy of the Pope's Universities, with a focus on Bologna, could be opened speaking about the expenses for the doctorate. In Bologna there were a lot of opportunities. The licentia, lower than a doctoral degree, was almost completely rejected in the early modern period. On the contrary the Bolognese title became a requirement for local students. It had high costs, about 50 roman scudi, which corresponded to 225 lire bolognine, for the private and the public exam (a requirement from the doctors from Bologna in order to teach at the Alma Mater Studiorum $)^{38}$. About $1 / 3$ less was required from foreign students in order to get the degree ${ }^{39}:$ the reason for the lower fee was that the forensium doctorate were excluded from the opportunity to teach in the Bolognese Studium. Some institutions could propose students to gain a doctorate free of charge and other students could ask for handouts ${ }^{40}$. The costs of the doctorate also refer to the division of money earned by the doctorate exclusively among the members of the exam commissions: the doctoral Colleges consisting of 16 doctors for the civil law, 12 for the canon law and 12 for medicine and philosophy ${ }^{41}$. About this subject we have the registers of distributions of money, for the years 1560-1800, for each doctoral College $\mathrm{e}^{42}$. These numbers show how high were the earnings of those

${ }^{37}$ Andrea Daltri, "Memorie e consigliature nella decorazione parietale dell'Archiginnasio", Imago Universitatis. Celebrazioni e autorappresentazioni di maestri e studenti nella decorazione parietale dell'Archiginnasio, t. I, ed. Gian Paolo Brizzi (Bologna : Bononia University Press, 2011), 31-50.

${ }^{38}$ Maria Teresa Guerrini, "Norma e prassi nell'esame di laurea in diritto a Bologna (14501800)", Storicamente 3 (2007): http://www.storicamente.org/01_fonti/guerrini.html; Piero Del Negro, "Le università italiane nella prima età moderna", Storia delle Università in Italia, t. I, eds. Gian Paolo Brizzi, Piero Del Negro, Andrea Romano (Messina : Sicania, 2007), 95-136. Some tables, containing the expenses for the degree Bologna, are in Archivio di Stato, Studio, Lauree. Depositi e spese per i dottorati, b. 262.

${ }^{39}$ Guerrini, "Norma e prassi nell'esame di laurea".

${ }^{40}$ On poor student see Sante Bortolami, "Gli studenti delle università italiane: numero, mobilità, distribuzione, vita studentesca dalle origini al XV secolo", Storia delle Università in Italia, t. II, eds. by Gian Paolo Brizzi - Piero Del Negro - Andrea Romano (Messina : Sicania, 2007), 65-115.

${ }^{41}$ Maria Teresa Guerrini, "Una corporazione per il potere: i collegi dei dottori di diritto bolognesi d'età moderna tra conservazione, autonomia e tutela", Examens, grades et diplômes. La validation des compétences par les universités du XIIe siècle à nos jours, ed. Thierry Kouamé (Paris : Editions de la Sorbonne, in print).

${ }^{42}$ Bologna, Archivio di Stato, Studio, Collegi Legali, Comparti e distribuzioni di somme ai dottori collegiati (1560-1713, 1792-1800), b. 178-180; Collegi di Medicina e d'Arti, Libri delle distribuzioni (1666-1739), b. 308. 
who occupied the position of doctor of College who could be asked to offer also legal consultations (the consilia sapientis) ${ }^{43}$, administrate the Gabella Grossa, manage the money destined for poor young women who could not afford a dowry, by Luigi Ratta at the end of the $16^{\text {th }}$ century, and some privileges on the appointment of the Avvocato dei Poveri for criminal trials in the city ${ }^{44}$.

\section{The wealth of doctors}

One graduate could therefore be, at the same time, teacher, member of doctoral College, private or public lawyer/doctor. In Bologna a professor could also give private lessons in the times established by the law ${ }^{45}$. The gains earned by doctors, in some cases, could therefore be considerable. To demonstrate the economic power of graduates, I would like to mention Gregorio Vernizzi as example of a doctor in law who lived in the middle of the $18^{\text {th }}$ century. He came from a non-noble family: his great-grandfather, Ugo, and his grandfather Egidio were the beadles at the Schools. The Vernizzi family had recently been admitted to the city patriciate and the doctorate was probably useful for social growth ${ }^{46}$. Gregorio was a man of humble origins, only the son of Vincenzo Maria, a simple tribune of the plebs (legacy of the glorious municipality of Bologna ${ }^{47}$ and stendardiere, but his cousin, Giuseppe Maria

${ }^{43}$ Giovanna Morelli, "Ne tacenda loquatur et dicenda conticeat. I consilia dei collegi legali bolognesi del XVI-XVIII secolo", Honos alit artes. Studi per il settantesimo compleanno di Mario Ascheri. La formazione del diritto comune. Giuristi e diritti in Europa (secoli XII-XVIII), eds. Paola Maffei, Gian Maria Varanini (Firenze : Firenze University Press, 2014), 109-118.

${ }^{44}$ Cesarina Casanova, "Gli avvocati dei poveri", Atlante delle professioni, ed. Maria Malatesta (Bologna : Bononia University Press, 2009), 121-123; Marco Cavina, "I luoghi della giustizia", Storia di Bologna. Bologna nell'età moderna (secoli XVI-XVIII). I. Istituzioni, forme del potere, economia e società, ed. Adriano Prosperi (Bologna : Bononia University Press, 2008), 367-399. In general, for all rights see Giovanna Morelli, "I Collegi di diritto nello Studio di Bologna tra XIV e XVII secolo", Il Carrobbio 8 (1982): 250-258.

${ }^{45}$ Maria Teresa Guerrini, "Tra docenza pubblica e insegnamento privato: i lettori dello Studio di Bologna in epoca moderna", Dalla lectura all'e-learning, ed. Andrea Romano (Bologna : CLUEB, 2015), 183-193.

${ }^{46}$ Alfeo Giacomelli, "Famiglie nobiliari e potere nella Bologna settecentesca", I "giacobini» nelle legazioni. Gli anni napoleonici a Bologna e Ravenna. Atti dei convegni di studi svoltisi a Bologna il 13-14-15 novembre 1996, a Ravenna il 21-22 novembre 1996, t. I, ed. Angelo Varni (S.l. : Costa, s.d.), 150. See also Bologna, Archivio di Stato, Ambasciata bolognese a Roma, Registrum, b. 137, 226 (1747), Aggregazione all'ordine nobile della famiglia Vernizzi [...] la quale per lungo corso di anni si è sempre resa distinta per ragguardevoli e virtuosi soggetti.

${ }^{47}$ Angela De Benedictis, Diritti in memoria, carità di patria. Tribuni della plebe e governo popolare a Bologna (XIV-XVIII secolo) (Bologna : CLUEB, 1999). 
(son of Ottavio, the professor), was appointed count by the Duke of Modena as appreciation for his service. His brother was Filippo Vernizzi, a famous clergyman ${ }^{48}$ that left him all his wealth. He had two uncles (Girolamo Maria and Giovanni Battista) who were appointed on the local Canon Chapters of San Petronio and of Santa Maria Maggiore.

Gregorio was born in Bologna in $1706^{49}$. He came from a new noble family, therefore his godparents were of the highest ranks of society: the princes of Piombino Gregorio and Ippolita Ludovisi Boncompagni, his wife, agreed to become Gregorio's godparents perhaps for the high position his uncle Girolamo Maria had in the hierarchy of the royal court in Poland ${ }^{50}$. Gregorio's brother Filippo had a noble godfather too, the prince Antonio Boncompagni Ludovisi, brother of Gregorio Boncompagni ${ }^{51}$. Gregorio Vernizzi took his iuris utriusque degree in $1728^{52}$, he was doctor of Colleges ${ }^{53}$, lawyer ${ }^{54}$, professor in the public University for 40 years ${ }^{55}$ and in his private home ${ }^{56}$ : during his career he accumulated many capitals. In the Studium he taught minor lectures, especially civil law lectures. After the discussion of the public conclusio-

${ }^{48}$ Guerrini, Collegi dottorali in conflitto. I togati bolognesi e la Costituzione di Benedetto XIV (1744). Filippo played an important role in the long debate against the Pope defending the rights of the doctors in Bologna.

${ }^{49}$ The right date of birth was the $21^{\text {st }}$ of August 1706 , he was baptized two days later (Bologna, Archivio di Stato, Studio, Registro delle aggregazioni al Collegio civile, b. 123, 37).

${ }^{50}$ Bologna, Biblioteca Comunale dell'Archiginnasio, B. 698, Baldassarre Antonio Maria Carrati, Alberi genealogici delle famiglie di Bologna, 119.

${ }^{51}$ Bologna, Archivio di Stato, Studio, Registro delle aggregazioni al Collegio civile, b. 123, 21, 1695.

${ }^{52}$ Maria Teresa Guerrini, Qui voluerit in iure promoveri ... I dottori in diritto nello Studio di Bologna (1501-1796) (Bologna : CLUEB, 2005), n. 8686, 26 June 1728.

${ }^{53} \mathrm{He}$ was admitted in the Civil Law College the 25 February 1734 (Bologna, Archivio di Stato, Studio, Costituzioni del Collegio civile, 1591, b. 16; Bologna, Biblioteca Comunale dell'Archiginnasio, Gozzadini 413, Aggiunta al libro de dottori bolognesi di legge civile e canonica laureati in Bologna doppo li 6 agosto del 1623, pubblicati dall'Alidosi condotta fino al 1811, 82) and the Canon Law College welcomed him the 7 May 1744 (ivi, Studio, Costituzioni del Collegio canonico, 1591, b. 6; Bologna, Archivio di Stato, Registro dei processi di aggregazione al Collegio canonico, b. 113, 33).

${ }^{54}$ His cursus honorum is described in Bologna, Archivio di Stato, Studio, Registro delle aggregazioni al Collegio civile, b. 123, 37.

${ }^{55}$ Dallari, I Rotuli dei lettori, legisti e artisti dello Studio bolognese, t. III/I and II, 353, 4-198.

${ }^{56}$ For the private lessons see Bologna, Archivio di Stato, Assunteria di Studio, Requisiti dei lettori, b. 58, f. 5 (1744), the document informs that Gregorio lectured at home to prepare young students to the final exam. In another document (ivi, Studio, Registro dei processi di aggregazione al Collegio canonico, b. 113, 33) it is explained that in the morning he taught at home canonical Institutions and in the afternoon he taught at the public Studium. In his home he housed students too. 
$n e s^{57}$, he started in 1736 with civil Institutiones and in 1739 he then taught the Ripetizioni di Bartolo until 1745, when he started teaching Malefici (in the years 1748-1749 he obtained a reserved seat). In 1749 he accepted the lectura of the Regole del diritto that he held until the 1751 with a reserved seat for teaching. From 1751 to 1753 he taught canon law with the Libro sesto e clementine (with a reserved seat for the years 1751 and 1752). During the academic year 1753-54 he returned to teaching Malefici and ended his teaching career, until 1776, with the Ripetizioni di Bartolo. His absence from the workplace, with the reserved seat, were probably due to his positions abroad (he was master cerimonies of the compatriot Pompeo Aldrovandi, archibishop of Montefiascone until 1752). During his teaching career he earned a salary of 200 lire bolognine per year, which increased to 300 lire at the end of his career $^{58}$ : not a high salary compared to the income of an ordinary professor of civil law who could earn at least 1.000/1.200 lire per year ${ }^{59}$.

Gregorio belonged to the lower noble side of the family because the comital title was passed bequeathed from the descendants of his cousin Giuseppe Maria. Despite this, when Gregorio died childless (in 1776) he had two servants (a man and a woman), a porter and a charioteer. He left a long testament (more than 170 pages) to administrate his legacy ${ }^{60}$ : his house was in Bologna under the parish of San Giorgio in Poggiale. He also had four other houses intra moenia ${ }^{61}$ and three hunting lodges: one in Olmetola (near Bologna) and two in San Lazzaro. In the will he mentions goods, paintings, jewels, money, credits, for an amount of 20.500 lire di bolognini ${ }^{62}$. He could claim 5019.3.5 lire and he had a debt of 3253.16.11 lire. However, in his will, there is a noticeable absence of books. We don't know why because he was a lawyer and he had a very big school in his home ${ }^{63}$, but in his will we did

${ }^{57}$ The conclusiones, a kind of thesis to be discussed after the graduation, were a requirement in order to have a chair in the public Studium. The conclusiones discussed by Gregorio Vernizzi in the Archiginnsaio building, the $12^{\text {th }}$ April 1731, are preserved in the State Archive of Bologna, Registro degli atti dell'Università degli scolari leggisti, b. 363, 67.

${ }^{58}$ Bologna, Archivio di Stato, Riformatori dello Studio, Quartironi degli stipendi, b. 53-54.

${ }^{59}$ Zannini, I Maestri: carriere, metodi didattici, posizione sociale, rapporti con le professioni.

${ }^{60}$ Bologna, Archivio di Stato, Notarile, Giovanni Battista Guarmani, 4 August 1776.

${ }^{61}$ One house (with four apartments) was in the Pratello quarter, another house was under the parish of Mascarella, one was in Santo Stefano and another under the parish of San Tommaso del Mercato (ibidem).

${ }^{62}$ 11108.15.6 lire of bolognini of goods, 1329 lire of clothes, 1060 lire in jewels, 761 lire of tables tools and money for 6352.3.0 lire (ibidem).

${ }^{63}$ See note 56. 
not find a list of books ${ }^{64}$, but there is a list of documents from his archive. Gregorio had accumulated a great amount of wealth thanks to his brother Filippo (professor of Criminal Practice at the University of Bologna for 49 years ${ }^{65}$ but, especially thanks to his knowledge: as teacher in the public University he had a modest salary, but he had great privileges in the Colleges of doctors $^{66}$ and good reputation as a private teacher. Among the people who benefitted from his inheritance there were his brother Girolamo Maria (retired servita general), his second cousin Ugo (son of the count Giuseppe Maria), his servants (Ludovico Pondrelli and Anna Diolaiti, the porter Gasparo Ugolini and Antonio Mantovani the charioteer), the parish priest of San Giorgio in Poggiale (Francesco Patrizio Cristofori) who received two legates, the Chapter and the Rectory of San Petronio where his brother Filippo and his cousin Gioacchino were involved and Elena Mingozzi, widow of his tenant Negri $^{67}$. Gregorio's family grew in social hierarchy thanks to his doctoral and professorial title ${ }^{68}$, starting from his cousin Giuseppe Maria and his brother Filippo; the inheritance was claimed by his second cousin Ugo, son of the count Giuseppe Maria.

\section{Conclusions}

During the early modern age we found different financial situations into the three Pope's Universities examined. Perugia heavily depended on Rome in the administration of the finances of its University, and it was the first University restored at the beginning of the $15^{\text {th }}$ century by Martino $V$ pope.

\footnotetext{
${ }^{64}$ Except those books inherited from his brother Filippo, who then he sells (Bologna, Archivio di Stato, Notarile, Giovanni Battista Guarmani, 4 August 1776).

${ }^{65}$ Dallari, I Rotuli dei lettori, legisti e artisti dello Studio bolognese, cit., t. III/I, 299-354, t. III/II, s. 4 - 182.

${ }^{66} \mathrm{He}$ was the Head of the Colleges of doctors many times. Head of the Civil Law College in 1738 (second bimester); 1740 (third bimester); 1743 (fifth bimester); 1749 (first and fourth bimester); 1753 (fourth bimester); 1757 (second bimester); 1759 (first bimester); 1764 (second bimester); 1767 (fourth bimester): Bologna, Archivio di Stato, Studio, Libri segreti del Collegio civile, b. 148-149. Head of the Canon Law College in 1740 (second semester); 1747 (second semester); 1753 (first semester); 1760 (second semester); 1766 (first semester); 1767 (first semester): Bologna, Archivio di Stato, Studio, Libri segreti del Collegio canonico, b. 136.

${ }^{67}$ Bologna, Archivio di Stato, Notarile, Giovanni Battista Guarmani, 4 August 1776.

${ }^{68}$ In addition to Gregorio and Filippo, their uncle Ottavio lectured in the Studium of Bologna too (Dallari, I Rotuli dei lettori, legisti e artisti dello Studio bolognese, cit., t. III/I, 49-183), his cousin Vincenzo Maria for 22 years (ivi, t. III/I, 321-353, t. III/II, 4-69), and his second cousin Ugo will teach there for 38 years (ivi, t. III/II, 129-324).
} 
The Sapienza of Rome depended by the Camera Urbis (the municipal administration irredeemably influenced, for its proximity, by the papacy). The Popes instead left to Bologna greater autonomy in the University administration of finances (run especially by doctors that became a power corporation without the medieval moral stature). This freedom however produced instability in the University of Bologna, political conflicts with disastrous consequences. Maybe this was not the right solution for Bologna and one of the advantages of this situation was an increase in the number of students in Rome ${ }^{69}$.

Nevertheless lawyers and doctors who graduated at the University of Bologna still had a very good reputation locally and great economic power, as the example of Gregorio Vernizzi shows, despite the competition from the graduates frome Rome who aimed for a career in the most important offices, both secular and ecclesiastical, of the Papal State. In contrast to repeating the same contents lecture after lecture. The topics would be in fact renewed only after the new wave of the French Revolution in the late $18^{\text {th }}$ century ${ }^{70}$.

The case study of Gregorio Vernizzi shows how much the testamentary document can be useful to reconstruct the economic condition of university professors in early modern period. Documents demonstrate how the income of a teacher included not only his salary, but also the proceeds from private lessons and the income from taking part to the exam commissions (the Colleges of doctors), which increased their earnings. The extremely valuable yet unexplored documentation kept in the archives in Bologna have the potential to open new perspectives on the financial administration of the University of Bologna during the early modern age. A research analyzing these features would contribute to demonstrate that the University of Bologna attempted, in the early modern period, to protect its independence claiming

${ }^{69}$ An example of this shift of preference (from Bologna to Rome) is studied for Sardinian students. See Maria Teresa Guerrini, "Un Regno senza Università: nuovi dati sulla presenza di studenti sardi nella Sapienza romana", Le origini dello Studio generale sassarese nel mondo universitario europeo dell'età moderna, eds. Gian Paolo Brizzi - Antonello Mattone (Bologna: CLUEB, 2013), 33-46

${ }^{70}$ About the renewal of the curricula and the teaching methods see Le università napoleoniche. Uno spartiacque nella storia italiana ed europea dell'istruzione superiore. Atti del Convegno internazionale di studi. Padova-Bologna, 13-15 settembre 2006, eds. Piero Del Negro and Luigi Pepe (Bologna : CLUEB, 2008); Dalla pecia all'e-book. Libri per l'Università: stampa, editoria, circolazione e lettura. Atti del Convegno internazionale di studi. Bologna, 21-25 ottobre 2008, eds. Gian Paolo Brizzi and Maria Gioia Tavoni (Bologna : CLUEB, 2009); Dalla lectura all'e-learning, ed. Andrea Romano (Bologna : CLUEB, 2015). 
the town autonomy in the Late Middle Ages ${ }^{71}$, when the pope was Niccolò V. Thus the research would help redefining not only the economic background, but also enriching the local political framework by including the city of Bologna and its Studium in a wider and new Italian and European context that goes beyond the traditional reputation of the Alma Mater Studiorum.

\section{Bibliography}

L'archivio dei Riformatori dello Studio. Inventario, ed. Claudia Salterini. Bologna : Istituto per la storia dell'Università, 1997.

BALDELli FranCA. "Tentativi di regolamentazione e riforme dello Studio bolognese nel Settecento", Il Carrobbio 10 (1984): 10-26.

Bortolami SANTE. "Gli studenti delle università italiane: numero, mobilità, distribuzione, vita studentesca dalle origini al XV secolo". Storia delle Università in Italia, t. II, eds. by Gian Paolo Brizzi - Piero Del Negro Andrea Romano. Messina : Sicania, 2007.

BRIZZI Gian PaOlo. "Lo Studio di Bologna fra orbis academicus e mondo cittadino". In Storia di Bologna. Bologna nell'età moderna. II. Cultura, istituzioni culturali, Chiesa e vita religiosa, ed. Adriano Prosperi. Bologna : Bononia University Press, 2008.

Casanova Cesarina. "Gli avvocati dei poveri". Atlante delle professioni, ed. Maria Malatesta. Bologna : Bononia University Press, 2009.

CAVAZZA MARTA. "Riforma dell'Università e nuove accademie nella politica culturale dell'Arcidiacono Marsili". Università, Accademie e Società scientifiche in Italia e in Germania dal Cinquecento al Settecento, eds. Laetitia Boehm and Ezio Raimondi. Bologna : il Mulino, 1981.

Cavazza Marta. Settecento inquieto. Alle origini dell'Istituto delle Scienze di Bologna. Bologna : il Mulino, 1990.

CAVInA MARCo. "I luoghi della giustizia". Storia di Bologna. Bologna nell'età moderna (secoli XVI-XVIII). I. Istituzioni, forme del potere, economia e società, ed. Adriano Prosperi. Bologna : Bononia University Press, 2008.

Cencetti Giongio. Lo Studio di Bologna. Aspetti momenti e problemi (19351970), eds. Roberto Ferrara, Gianfranco Orlandelli, Augusto Vasina. Bologna : CLUEB, 1989.

${ }^{71}$ On the topic of the negotiated freedom (the Bolognese libertas) see Tommaso Duranti, Diplomazia e autogoverno a Bologna nel Quattrocento (1392-1466). Fonti per la storia delle istituzioni (Bologna : CLUEB, 2009). 
Dalla lectura all'e-learning, ed. Andrea Romano. Bologna : CLUEB, 2015.

Dalla pecia all'e-book. Libri per l'Università: stampa, editoria, circolazione e lettura. Atti del Convegno internazionale di studi. Bologna, 21-25 ottobre 2008, eds. Gian Paolo Brizzi and Maria Gioia Tavoni. Bologna : CLUEB, 2009.

DALlARI Umberto. I Rotuli dei lettori, legisti e artisti dello Studio bolognese. Bologna : F.lli Merlani, 1888-1924.

DALTRI ANDREA. "Memorie e consigliature nella decorazione parietale dell'Archiginnasio". Imago Universitatis. Celebrazioni eautorappresentazioni di maestri e studenti nella decorazione parietale dell'Archiginnasio, t. I, ed. Gian Paolo Brizzi. Bologna : Bononia University Press, 2011.

De Benedictis Angela. Patrizi e comunità. Il governo del contado bolognese nel Settecento. Bologna : il Mulino, 1984.

De Benedictis Angela. Repubblica per contratto, Bologna: una città europea nello Stato della Chiesa. Bologna : il Mulino, 1995.

De Benedictis Angela. Diritti in memoria, carità di patria. Tribuni della plebe e governo popolare a Bologna (XIV-XVIII secolo). Bologna : CLUEB, 1999.

De Coster ANuschKa. La mobilità dei docenti: Comune e Collegi dottorali di fronte al problema dei lettori non cittadini nello Studio bolognese". In Studenti e dottori nelle università italiane (origini-XX secolo), ed. Gian Paolo Brizzi - Andrea Romano. Bologna : CLUEB, 2000.

De Coster AnuschKa. "L'immagine dei docenti forestieri negli statuti universitari e cittadini di Bologna e Padova (secoli XV-XVI)". In Gli Statuti universitari. Tradizione dei testi e valenze politiche, Atti del Convegno internazionale di studi, Messina-Milazzo, 13-18 aprile 2004, ed. Andrea Romano. Bologna : CLUEB, 2007.

De Coster Anuschka. "Foreign and Citizen Teachers at Bologna University in the 15th and 16th Centuries: Statutes, Statistics and Student Teachers", Annali di Storia delle Università italiane 12 (2008): 329-356.

Del Negro Piero. "Le università italiane nella prima età moderna". Storia delle Università in Italia, t. I, eds. Gian Paolo Brizzi, Piero Del Negro, Andrea Romano. Messina : Sicania, 2007.

DE RIDDER-SYMOENS HILDE. "Management and resources". In A history of the University in Europe. Volume II. Universities in Early Modern Europe, ed. Hilde de Ridder-Symoens. Cambridge : Cambridge University Press, 1996.

Di Simone Maria Rosa. La Sapienza romana nel Settecento. Organizzazione, università e insegnamento del diritto. Roma : Edizioni dell'Ateneo, 1980.

Duranti Tommaso. Diplomazia e autogoverno a Bologna nel Quattrocento (1392-1466). Fonti per la storia delle istituzioni. Bologna : CLUEB, 2009. 
ERMINI GIUSEPPE. Storia dell'Università di Perugia, t. 1. Bologna : Zanichelli, 1947. ANDREA GARDI. "Lineamenti della storia politica di Bologna: da Giulio II a Innocenzo X". In Storia di Bologna. Bologna nell'età moderna. I. Istituzioni, forme del potere, economia e società, ed. Adriano Prosperi. Bologna : Bononia University Press, 2008.

GARDI ANDREA. Lo Stato in provincia. L'amministrazione della Legazione di Bologna durante il regno di Sisto V (1585-1590). Bologna : Istituto per la storia di Bologna, 1994.

GiACOMELli AlFEo. "Famiglie nobiliari e potere nella Bologna settecentesca". I «giacobini» nelle legazioni. Gli anni napoleonici a Bologna e Ravenna. Atti dei convegni di studi svoltisi a Bologna il 13-14-15 novembre 1996, a Ravenna il 21-22 novembre 1996, t. I, ed. Angelo Varni. S.l. : Costa, s.d. GIACOMELLI ALFEO. "L'età moderna (dal XVI al XVIII secolo)". In L'Università a Bologna. Maestri, studenti e luoghi dal XVI al XX secolo. Bologna : Cassa di Risparmio, 1988.

GIERYSZTOR ALEKSANDER. "Management and resources". In A history of the University in Europe. Volume I. Universities in the Middle Ages, ed. Hilde de Ridder-Symoens. Cambridge : Cambridge University Press, 1992.

GUerrini MARIA Teresa. Qui voluerit in iure promoveri ... I dottori in diritto nello Studio di Bologna (1501-1796). Bologna : CLUEB, 2005.

Guerrini MARIA TERESA. "Norma e prassi nell'esame di laurea in diritto a Bologna (1450-1800)". Storicamente 3 (2007): http://www.storicamente.org/01_fonti/guerrini.html.

Guerrini Maria Teresa. Collegi dottorali in conflitto. I togati bolognesi e la Costituzione di Benedetto XIV (1744). Bologna : CLUEB, 2012.

Guerrini Maria TEResa. "Tra docenza pubblica e insegnamento privato: i lettori dello Studio di Bologna in epoca moderna". Dalla lectura all'elearning, ed. Andrea Romano. Bologna : CLUEB, 2015.

Guerrini Maria Teresa. "Conflitti corporativi fra dottori bolognesi, ferraresi e romani intorno a titoli accademici e professioni (1626-1795)". Un monopolio imperfetto. Titoli di studio, professioni, università (secc. XIV-XXI), eds. Maria Teresa Guerrini, Regina Lupi, Maria Malatesta. Bologna : il Mulino, 2016.

LUPI REGINA. Gli studia del papa. Nuova cultura e tentativi di riforma tra Sei e Settecento. Firenze : Centro Editoriale Toscano, 2005.

MARSILI ANTON FELICE. Memorie per riparare i pregiudizi dell'Università dello Studio di Bologna, e ridurlo ad una facile e perfetta riforma (Bologna : s.l., 1689) in Ettore Bortolotti, "La fondazione dell'Istituto e la Riforma dello Studio di Bologna", Memorie intorno a Luigi Ferdinando Marsi- 
li pubblicate nel secondo centenario della morte per cura del Comitato Marsiliano. Bologna : Zanichelli, 1930.

Marsili Anton Felice. Delle prerogative del Cancellierato Maggiore dello Studio generale di Bologna carico depositato nell'Arcidiacono della Metropolitana di essa Città raccolte da monsignore Antonio Felice Marsili moderno Arcidiacono, e Maggior Cancelliere. Bologna : s.l., 1692.

Morelli Giovanna. "I Collegi di diritto nello Studio di Bologna tra XIV e XVII secolo". Il Carrobbio 8 (1982): 250-258.

Morelli GiovanNa. "Ne tacenda loquatur et dicenda conticeat. I consilia dei collegi legali bolognesi del XVI-XVIII secolo". Honos alit artes. Studi per il settantesimo compleanno di Mario Ascheri. La formazione del diritto comune. Giuristi e diritti in Europa (secoli XII-XVIII), eds. Paola Maffei, Gian Maria Varanini. Firenze : Firenze University Press, 2014.

PARMEgGiani RicCARDo. "L'ARCIDIACONO Bolognese TRA ChiESA, CitTà E Studium". L'Università in tempo di crisi. Revisioni e novità dei saperi e delle istituzioni nel Trecento, da Bologna all'Europa, eds. Berardo Pio - Riccardo Parmeggiani. Bologna : CLUEB, 2016.

Pini Antonio Ivan. "Per una storia sociale dell'Università: i bidelli bolognesi nel XIII secolo". Studio, università e città nel medioevo bolognese. Bologna : CLUEB, 2005.

Renazzi Filippo Maria. Storia dell'Università degli studi di Roma. Detta comunemente la Sapienza che contiene anche un saggio storico della letteratura romana, dal principio del secolo XIII sino al declinare del secolo XVIII. Roma : stamperia Pagliarini, 1806.

Romano AndREA. "Dall'Università degli Studenti all'Università degli Studi. Modelli di finanziamento delle Università italiane fra medioevo ed età moderna". In Finanzierung von Universität und Wissenschaft in Vergangenheit und Gegenwart, ed. Rainer Christoph Schwinges. Basel : Schwabe Verlag, 2005.

Le università napoleoniche. Uno spartiacque nella storia italiana ed europea dell'istruzione superiore. Atti del Convegno internazionale di studi. Padova-Bologna, 13-15 settembre 2006, eds. Piero Del Negro and Luigi Pepe. Bologna : CLUEB, 2008.

ZANNINI ANDREA. "I Maestri: carriere, metodi didattici, posizione sociale, rapporti con le professioni". Storia delle Università in Italia, t. II, eds. Gian Paolo Brizzi, Piero Del Negro, Andrea Romano. Messina : Sicania, 2007. Zucchini Stefania. Università e dottori nell'economia del comune di Perugia. Perugia : Deputazione di storia patria per l'Umbria, 2008. 